\title{
Lypsylehmän energiataseen mallintaminen
}

\author{
Tuomo Kokkonen ${ }^{1)}$ Päivi Mäntysaari2 ${ }^{2)}$ ja Pekka Huhtanen ${ }^{3)}$ \\ ${ }^{1)}$ Kotieläintieteen laitos, PL 28,00014 Helsingin yliopisto; etunimi.sukunimi@helsinki.fi \\ ${ }^{2)}$ MTT, Kotieläintuotannon tutkimus, Maidon ja naudanlihan tuotanto, H-talo, 31600 Jokioinen \\ ${ }^{3)}$ Department of Agricultural Research for Northern Sweden, Swedish University of Agricultural \\ Sciences, S-901 83 Umeå, Sweden
}

Lypsylehmät ovat tuotoskauden alkuvaiheessa tyypillisesti negatiivisessa energiataseessa, kun energian tarve kasvaa maitotuotoksen lisääntyessä nopeammin kuin energian saanti rehusta. Energiavajausta täydentääkseen lehmät mobilisoivat kudoksiensa rasvavarastoista rasvahappoja ja glyserolia. Lehmät mobilisoivat kudoksistaan myös aminohappoja, vaikka niillä ei rasvavarastoihin verrattavissa olevia valkuaisvarastoja. Tuotoshuipun jälkeen, rehun syönnin lisääntyessä, energiatase kääntyy vähitellen positiiviseksi ja lehmät alkavat jälleen kartuttaa mobilisoituja kudosvarastojaan. Kudosvarastojen kartuttaminen jatkuu loppulypsykauden ja ummessaolokauden ajan, aina seuraavaan poikimiseen saakka.

Tuotoskauden alun negatiivinen energiatase on lehmille luonnollinen sopeutumismekanismi, johon liittyy varsin monimutkainen hormonaalinen säätely. Jalostusvalinta on kuitenkin tuottanut lehmiä, joiden kyky tuottaa runsaasti maitoa perustuu osittain lisääntyneeseen taipumukseen mobilisoida kudosvarastoja, vaikka myös rehunsyöntikyky on lisääntynyt jalostusvalinnan myötä. Lisääntynyt kudosmobilisaatio ja syvempi energiataseen vaje ovat lisänneet lehmien hedelmällisyysja terveysongelmia. Voimakkaasti negatiivinen energiatase viivästyttää kiimakiertojen alkamista ja heikentää tiinehtyvyyttä. Runsas rasvahappojen mobilisaatio lisää rasvan kertymistä maksaan, mikä voi haitata maksan toimintaa. Lisääntyneen ketoainetuotannon on todettu heikentävän immuunijärjestelmän toimintaa. Voimakas metabolinen stressi saattaa myös vaikuttaa lehmien käyttäytymiseen ja heikentää niiden hyvinvointia.

Lehmien alkulypsykauden energiavajausta pyritään yleensä vähentämään lisäämällä väkirehun osuutta ruokinnassa. Liian runsas väkirehuruokinta lisää kuitenkin pötsin happamoitumisen riskiä, heikentää karkearehun sulavuutta ja on tuotosvasteeltaan tehotonta. Myös valkuaisruokinta vaikuttaa energiataseeseen: runsas aminohappojen saanti pyrkii lisää maitotuotosta ja lisää siten energian tarvetta.

Lypsykauden keski- ja loppuosa ja ummessaolokausi, jolloin lehmät ovat yleensä positiivisessa energiataseessa, ovat lehmien terveyden kannalta huomattavasti ongelmattomampia kuin tuotoskauden alku. Tässä vaiheessa on kuitenkin vältettävä yliruokintaa ja lehmien liiallista lihomista, koska lihavien lehmien energiatase poikimisen jälkeen on negatiivisempi kuin normaalikuntoisten. Yliruokinta on myös taloudellisesti tehotonta.

Tutkimuksessa mallinnetaan lypsylehmän energiatasetta tuotoskauden eri vaiheissa. Aineistona käytetään aiemmissa kotimaisissa tutkimuksissa kerättyjä lehmäkohtaisia syönti- ja tuotostietoja, jotka analysoidaan meta-analyysin avulla siten, että tutkimusolosuhteiden (mm. paikka) vaikutus huomioidaan mallissa satunnaistekijänä. Väkirehun osuuden ja ruokinnan valkuaispitoisuuden vaikutusta testataan lisäämällä nämä tekijät tilastolliseen malliin. Lisäksi mallissa huomioidaan poikimakerta. Mallinnuksessa saatua tietoa energiataseen muutoksesta tuotoskauden aikana sekä ruokinnan vaikutuksesta energiataseeseen voidaan käyttää ruokinnan suunnittelun kehittämisen työkaluna. Energiataseen mallintamisen lisäksi testataan sen ennustamista tilatasolla käytettävissä olevan tiedon (kuntoluokka, maidon pitoisuuden muutokset) perusteella.

Asiasanat: lypsylehmä, energiatase, kudosvarastot, kuntoluokka, syönti, maitotuotos 


\section{Johdanto}

Tuotoskauden alussa lypsylehmä sopeutuu poikimisen ja voimakkaasti lisääntyvän maidontuotannon aiheuttamiin tarpeisiin mobilisoimalla rasvaa, aminohappoja ja kivennäisaineita kudoksistaan. Runsastuottoiset lypsylehmät käyttävät poikimisen jälkeen useiden viikkojen ajan kudosten rasvavarastoja täyttääkseen energiavajetta, joka syntyy maitotuotoksen lisääntyessä rehunsyöntiä nopeammin. Myös aminohappojen mobilisaatio voi jatkua useiden viikkojen ajan, kun taas kivennäisaineiden mobilisaatio painottuu poikimisen välittömään läheisyyteen.

Lypsylehmän energiatase on yleensä negatiivinen tuotoskauden alkuvaiheessa. Energiavajeen suuruudessa on suuria lehmien välisiä eroja, joiden taustalla on sekä perinnöllisiä että hoitokäytäntöihin liittyviä tekijöitä. Energiavajeen suuruuden arvioiminen tilaolosuhteissa on lyhyellä aikavälillä vaikeaa, koska rehujen syöntiä ei voida mitata ja siten lehmän energian saantia ei tiedetä tarkasti. Lehmiä ei myöskään yleensä pystytä punnitsemaan tiloilla, joskin lypsyrobottitiloilla tämä mahdollisuus on. Pidemmällä aikavälillä lehmän energiatasetta voidaan tilaolosuhteissa seurata kuntoluokituksen avulla. Kuntoluokan lasku korreloi rasvan mobilisaatioon ja vastaavasti kuntoluokan nousu rasvan kertymiseen.

Negatiivisella energiataseen kesto, erityisesti syvimmän energiavajeen ajoittuminen, vaikuttaa vahvasti lehmien hedelmällisyyteen. Pitkittynyt energiavaje siirtää kiimakiertojen käynnistymistä ja viivästyttää siten siemennystä ja seuraavaa tiinehtymistä. Runsas kudosrasvan mobilisaatio lisää maksan rasvoittumista, mikä saattaa heikentää maksan normaalia toimintaa, erityisesti glukoosin tuotantoa (Rukkwamsuk ym. 1999, Loor ym. 2006) ja maksan kykyä hapettaa rasvahappoja (Murondoti ym. 2004). Voimakas rasvakudoksen mobilisaatio lisää myös ketoosin riskiä.

Tuotoshuipun jälkeen lehmän energiatase kääntyy positiiviseksi. Tuotoskauden keski- ja loppuvaihe ovat yleensä alkuvaihetta huomattavasti ongelmattomampia. Lehmä käyttää ylimääräisen energian alkuvaiheessa mobilisoitujen kudosvarastojen palauttamiseen ja myöhemmin kartuttaa uusia varastoja valmistautuessaan seuraavan tuotoskauden alkuun. Ongelmana on lähinnä liiallisen lihomisen välttäminen, koska liika lihominen lypsykauden lopulla altistaa lehmän voimakkaasta rasvakudoksen mobilisaatiosta johtuville ongelmille seuraavan poikimisen yhteydessä.

\section{Energiatase: kudosvarastojen käyttö ja terveys}

Lehmän rehunsyöntikyky ei kehity poikimisen jälkeen yhtä nopeasti kuin sen maitotuotos nousee, joten lehmä joutuu täyttämään energia- ja ravintoainevajetta mobilisoimalla rasvaa, valkuaista ja kivennäisaineita kudoksistaan (Ingvartsen ja Andersen 2000, Kokkonen 2005). Rasvan ja valkuaisen mobilisaatiota kudoksista edistää veren insuliinipitoisuuden aleneminen ja kudosten insuliiniresistenssin voimistuminen poikimisen lähestyessä. Insuliiniresistenssillä tarkoitetaan tilaa, jossa haima tuottaa insuliinia, mutta sen teho on heikentynyt ja siksi ääreiskudosten glukoosin käyttö vähenee ja lipolyysi lisääntyy. Insuliiniresistenssin lisääntyminen on lehmälle keino ohjata glukoosia sekä amino- ja rasvahappoja sikiölle ja alkavan runsaan maidon tuotannon tarpeisiin. Insuliinipitoisuus pysyy alhaisena ja insuliinin vaikutus heikentyneenä ensimmäisten tuotosviikkojen aikana. Korkeatuottoisiksi jalostetuilla lehmillä insuliiniresistenssi on voimakkaampi kuin vähemmän maitoa tuottavilla (Chagas ym. 2009).

Kudosmobilisaatiota edistää kasvuhormonin korkea pitoisuus veressä poikimisen aikaan ja laktaation alussa. Kasvuhormoni voimistaa lipolyysiä lisäämällä vastetta katekoliamiinien $\beta$ adrenergisille signaaleille. Kasvuhormoni myös heikentää insuliinin signaalin välittymistä (lisää insuliiniresistenssiä) rasva- ja lihaskudoksessa (del Rincon ym. 2007).

Runsaan maidontuotannon aiheuttama metabolinen stressi altistaa lehmän sairastumiselle. Poikimisen läheisyydessä myös lehmän immuunijärjestelmän toiminta on tilapäisesti heikentynyt. Suurin osa lehmien sairastumisista (mm. poikimahalvaus, asetonitauti, utaretulehdus) havaitaan poikimisen läheisyydessä tai muutamien viikkojen kuluessa poikimisesta. Negatiivisen energiataseen vaikutus immuunijärjestelmän toimintaan ja sairastumisalttiuteen on ilmeisesti epäsuora. Runsaaseen rasvakudosmobilisaatioon liittyy usein ketoaineiden pitoisuuden nousu, mikä heikentää immuunipuolustuksen toimintaa (Overton ja Waldron 2004).

Friggensin ym. (2004) mukaan ruumiin rasvavarastojen muutos voidaan jakaa geneettisesti määräytyvään ja ympäristötekijöistä aiheutuvaan. Geneettisesti määräytyvä muutos ilmeisesti tapahtuu, vaikka mikään ympäristötekijä (esim. muutokset ravinnon saannissa) ei sitä edellyttäisi. Rasvakudoksen mobilisaatio voi siten olla paitsi energian saannin puutteesta aiheutuvaa, myös osittain 
geneettisesti määräytyvää. Korkeatuottoisiksi jalostetut rodut mobilisoivat kudosvarastojaan enemmän kuin vähemmän tuottavat rodut. Vastaavasti ensikot mobilisoivat vähemmän kuin toisen tai useamman kerran poikineet lehmät (Friggens ym. 2007a).

Keski- ja loppulaktaation aikana lypsylehmät kartuttavat uudelleen alkulaktaatiossa kulutettuja rasvavarastoja $\mathrm{Ne}$ pystyvät tällöin kompensoimaan melko suuriakin puutteita alkulaktaation ruokinnassa. Lehmillä on ilmeisesti geneettinen taipumus pyrkiä palauttamaan tietty ruumiinvarastojen taso laktaation keski- ja loppuvaiheessa sekä seuraavan ummessaolokauden aikana (Friggens ym. 2004). Yliruokinta näissä vaiheissa johtaa kuitenkin helposti liialliseen lihomiseen, mikä aiheuttaa ongelmia seuraavan tuotoskauden alussa. Lypsykauden lopulla lehmät pystyvät ohjaamaan "ylimääräistä" energiaa osittain maitotuotokseen, mikäli valkuaissaanti on riittävä, mutta ummessaolokaudella tätä mahdollisuutta ei ole (Friggens ym. 2004). Ummessaolevat lehmät eivät vapaassa ruokinnassa säätele rehun syöntiään energian tarpeen mukaan vaan syövät usein noin 150 $160 \%$ energian tarpeestaan (Loor ym. 2006).

\section{Energiatase ja hedelmällisyys}

Lypsylehmien hedelmällisyys on heikentynyt viime vuosikymmenten aikana, samanaikaisesti kun maitotuotos on kasvanut. Royal ym. (2000) raportoivat, että Isossa-Britanniassa tiinehtyminen ensimmäiseen siemennykseen putosi 55,6 \%:sta 39,7 \%:iin 1970-luvun lopulta 1990-luvun lopulle tultaessa. Butlerin (2003) mukaan myös amerikkalaisissa karjoissa tiinehtyvyys on heikentynyt vastaavasti. Tiinehtyvyyden heikentymistä on selitetty korkeatuottoisten lehmien voimakkaasti negatiivisella energiataseella. Siemennystä edeltävien kiimakiertojen määrän on osoitettu korreloivan positiivisesti tiinehtyvyyden kanssa. Tiinehtyvyyden kannalta on edullista, että energiavaje ei ole kovin voimakas ja että energiavaje alkaa pienentyä mahdollisimman aikaisin (Butler 2003).

Liian lihavien lehmien tiinehtyvyys on tyypillisesti heikko, koska niiden energiatase on voimakkaasti negatiivinen. Ne mobilisoivat runsaasti rasvavarastojaan, jolloin niiden rehun syönti lisääntyy hitaammin kuin laihempien lehmien (Rukkwamsuk ym. 1999, Kokkonen 2005). Lihavien lehmien rasvamobilisaatio on voimakkaampaa ja niiden veren NEFA-pitoisuus on suurempi kuin laihempien lehmien jo poikimista edeltävällä viikolla (Kokkonen ym. 2005). Runsaalla veren NEFApitoisuudella voi olla kudosten insuliiniherkkyyttä heikentävä vaikutus (Pires ym. 2008). Salin ym. (2010) osoittivat, että veren NEFA-pitoisuuden nosto 5 päivää kestävällä rasvainfuusiolla juoksutusmahaan riitti heikentämään ummessaolevien lehmien insuliiniherkkyyttä glukoosirasituskokeessa. NEFA-pitoisuuden nousu ilmeisesti myös heikentää haiman kykyä erittää insuliinia. Salinin ym. (2010) kokeessa rasvainfuusio alensi insuliinin perustasoa suuntaa-antavasti. Myös Bossaertin ym. (2008) tutkimuksen tulokset viittaavat siihen, että NEFA-pitoisuuden nousu heikentää glukoosin stimuloimaa insuliinin eritystä lypsylehmillä.

Negatiivisen energiataseen tiinehtyvyyttä heikentävä vaikutus välittyy useilla eri tavoilla. Negatiivisen energiataseen on osoitettu vähentävän lutenisoivan hormonin pulssimaista eritystä, mikä vähentää ovulaation todennäköisyyttä (Butler 2003). Negatiivisessa energiataseessa insuliinin pitoisuus laskee, mikä heikentää insuliinin follikkelien kasvua stimuloivaa vaikutusta. Insuliinin kaltaisen kasvutekijä I:n (IGF-I) pitoisuuden vähenemisellä on samankaltainen vaikutus. Insuliinin ja IGF-I:n pitoisuus vaikuttaa ilmeisesti myös follikkelien kykyyn erittää riittävästi estradiolia (Beam ja Butler 1999).

\section{Energiataseen mittaaminen}

Lypsylehmän energiatase voidaan määrittää kolmella tavalla: 1) energian saannin ja tuotokseen käytetyn energian erotuksena, 2) ruumiin varastojen muutoksen kautta ja 3) maidon koostumusten muutosten kautta (Friggens ym. 2007b). Ensin mainitussa menetelmässä rehun syönti ja rehun energiasisältö on pystyttävä mittaamaan tarkasti. Lisäksi eläin on pystyttävä punnitsemaan (elopainon muutos, sikiön kasvu). Tilaolosuhteissa syönnin tarkka mittaaminen ei ole mahdollista ja eläinten punnitus on mahdollista melko harvoilla tiloilla. Ongelmat edustavan säilörehunäytteen saamisessa sekä epätarkkuus säilörehun kuiva-aineen ja rehujen energia-arvon määrityksessä voivat heikentää energian saannin mittaustarkkuutta. Koe-olosuhteissa energiantaseen määrittämistä energian saannin ja tuotoksen kautta voidaan kuitenkin pitää standardimenetelmänä, johon muita määritystapoja verrataan. 
Ruumiin varastojen muutos voidaan määrittää elopainon ja kuntoluokan muutosten kautta. Näistä kuntoluokitus on käyttökelpoinen menetelmä tilaolosuhteissa. Ongelmana on kuntoluokituksen epäherkkyys muutosten havaitsemiseen lyhyellä aikavälillä. Elopainon muutoksen mittaamisen luotettavuutta tuotoskauden alussa heikentävät samaan aikaan tapahtuvat muutoksen rehun syönnissä (ruoansulatuskanavan paino muuttuu) ja maitotuotoksessa. Energiataseen määrittäminen elopainon ja kuntoluokan muutosten kautta sisältää myös oletuksen siitä, kuinka suurta rasva- ja valkuaisvarastojen muutosta yhden elopainokilon tai kuntoluokkayksikön muutos vastaa (Coffey ym. 2001).

Maidon koostumuksen muutosten käyttäminen energiataseen indikaattorina perustuu rasva- ja valkuaispitoisuuksien muutokseen energian saannin vaihdellessa. Niukka energiansaanti vähentää ja runsas energiansaanti lisää maidon valkuaispitoisuutta. Negatiivisessa energiataseessa kudosrasvan mobilisaatio lisääntyy, mikä lisää maidon rasvapitoisuutta ja kasvattaa pitkäketjuisten rasvahappojen osuutta maitorasvasta (Friggens ym. 2007b). Maitonäytteiden ottaminen on helppoa ja analyysikustannukset ovat edullisia, mikä tekee energiataseen määrittämisestä maidon koostumuksen kautta tilatasolla potentiaalisesti hyvin käyttökelpoisen vaihtoehdon. Lisäksi maitonäytteitä on tiloilla totuttu ottamaan rutiininomaisesti tuotostarkkailua varten.

\begin{abstract}
Aineisto
Energiataseen mallintamista varten KarjaKompassi-hankkeessa on koottu suomalaisten lypsylehmillä tehtyjen kokeiden tuloksia. Käytettävissä olevassa aineistossa on yhdeksän Helsingin yliopiston Kotieläintieteen laitoksella tehtyä, tuotoskauden alkuvaiheeseen painottuvaa koetta. Näiden kokeiden kesto oli 8 - 12 viikkoa alkaen poikimisesta. Lisäksi aineistoon sisältyy MTT:llä tehtyjä alkuvaiheesta pidemmälle lypsykautta ulottuvia kokeita. Kokeista on tallennettu lehmäkohtaisesti viikoittaiset tiedot maitotuotoksesta, maidon koostumuksesta, väki- ja karkearehujen syönnistä, elopainosta ja kuntoluokasta.

Tutkimuksessa mallinnetaan lypsylehmän energiatasetta tuotoskauden eri vaiheissa. Aineistona käytetään aiemmissa kotimaisissa tutkimuksissa kerättyjä lehmäkohtaisia syönti- ja tuotostietoja, jotka analysoidaan siten, että tutkimusolosuhteiden (mm. paikka) vaikutus huomioidaan mallissa satunnaistekijänä. Väkirehun osuus, ruokinnan valkuaispitoisuus ja poikimakerta huomioidaan mallissa. Mallinnuksessa saatua tietoa energiataseen muutoksesta tuotoskauden aikana sekä ruokinnan vaikutuksesta energiataseeseen voidaan käyttää ruokinnan suunnittelun kehittämisen työkaluna. Energiataseen mallintamisen lisäksi testataan sen ennustamista tilatasolla käytettävissä olevan tiedon (kuntoluokka, maidon pitoisuuden muutokset) perusteella.
\end{abstract}

\title{
Kirjallisuus
}

Beam, S.W. \& Butler, W.R. 1999. Effects of energy balance on follicular development and first ovulation in postpartum dairy cows. Journal of Reproduction and Fertility Suppl 54: 411-424.

Bossaert, P., Leroy, J.L.M.R., De Vliegher, S. \& Opsomer, G. 2008. Interrelations between glucose-induced insulin response, metabolic indicators, and time of first ovulation in high-yielding dairy cows. Journal Dairy Sci. 91: 3363-3371.

Butler, W.R. 2003. Energy balance relationships with follicular development, ovulation and fertility in postpartum dairy cows. Livestock Production Science 83: 211-218.

Chagas, L.M., Lucy, M.C., Back, P.J., Blache, D., Lee, J.M., Gore, P.J.S., Sheahan, A.J. \& Roche, J.R. 2009. Insulin resistance in divergent strains of Holstein-Friesian dairy cows offered fresh pasture and increasing amounts of concentrate in early lactation. Journal of Dairy Science 92: 216-222.

Coffey, M.P., Emmans, G. C. \& Brotherstone, S. 2001. Genetic evaluation of dairy bulls for energy balance traits using random regression. Animal Science 73: 29-40.

del Rincon, J.P., Iida, K., Gaylinn, B.D., McCurdy, C.E., Leitner, J.W., Barbour, L.A., Kopchick, J.J., Friedman, J.E., Draznin, B. \& Thorner, M.O. 2007. Growth hormone regulation of p85 alpha expression and phosphoinositide 3-kinase activity in adipose tissue: mechanism for growth hormone-mediated insulin resistance. Diabetes 56: 1638-1646.

Friggens, N.C., Berg, P., Theilgaard, P., Korsgaard, I.R., Ingvartsen, K.L., Løvendahl, P.L. \& Jensen, J. 2007a. Breed and parity effects on energy balance profiles through lactation: evidence for genetically driven body reserve change. Journal of Dairy Science 90: 5291-5305.

Friggens, N.C., Ingvartsen, K.L. \& Emmans, G.C. 2004. Prediction of body lipid change in pregnancy and lactation. Journal of Dairy Science 87: 988-1000.

Friggens, N.C., Ridder, C. \& Løvendahl, P.L. 2007b. On the use of milk composition measures to predict the energy balance of dairy cows. Journal of Dairy Science 90: 5291-5305. 
Ingvartsen, K.L. \& Andersen, J.B. 2000. Integration of metabolism and intake regulation: A review focusing on periparturient animals. Journal of Dairy Science 83: 1573-1597.

Kokkonen, T. 2005. Energy and protein nutrition of dairy cows during the dry period and early lactation: production performance and adaptation from pregnancy to lactation. Diss., University of Helsinki. Department of Animal Science, Publications 77. 56 p. + 4 encl. Saatavissa: http://urn.fi/URN:ISBN:952-10-1746-5

Kokkonen, T., Taponen, J., Anttila, T., Syrjälä-Qvist, L., Delavaud, C., Chilliard, Y., Tuori, M., Tesfa, A.T. 2005. Effect of body fatness and glucogenic supplement on lipid and protein mobilization and plasma leptin in dairy cows. Journal of Dairy Science 88: 1127-1141.

Loor, J.J., Dann, H.M., Janovick Guretzky, N.A., Everts, R.E., Oliveira, R., Green, C.A., Litherland, N.B., Rodriguez-Zas, S.L., Lewin H.A., Drackley, J.K. 2006. Plane of nutrition prepartum alters hepatic gene expression and function in dairy cows as assessed by longitudinal transcript and metabolic profiling. Physiological Genomics 27: 29-41.

Murondoti, A., Jorritsma, R., Beynen, A.C., Wensing, T. \& Geelen, M.J.H. 2004. Unrestricted feed intake during the dry period impairs the postpartum oxidation and synthesis of fatty acids in the liver of dairy cows. Journal of Dairy Science 87: 672-679.

Overton, T.R. \& Waldron, M.R. 2004. Nutritional management of transition dairy cows: strategies to optimize metabolic health. Journal of Dairy Science 87 (E. Suppl.): E105-E119.

Pires, J.A.A, Pescara, J., Brickner, A., Rio, N., Cunha, A.P. \& Grummer, R.R. 2008. Effects of abomasal infusion of linseed oil on responses to glucose and insulin in Holstein cows. Journal of Dairy Science 91: 13781390.

Royal, M.D., Darwash, A.O., Flint, A.P.F., Webb, R., Woolliams, J.A. \& Lamming, G.E. 2000. Declining fertility in dairy cattle: changes in traditional and endocrine parameters of fertility. Animal Science 70: 487-501. Rukkwamsuk, T., Wensing, T., Geelen, M.J.H. 1999. Effect of fatty liver on hepatic gluconeogenesis in periparturient dairy cows. Journal of Dairy Science 82: 500-505.

Salin, S., Kokkonen, T., Kuitunen, M., Taponen, J., Elo, K. \& Vanhatalo, A. 2010. Juoksutusmahaan infusoidun rasvalisän vaikutus ummessaolevien lehmien insuliiniresistenssin kehittymiseen. Julkaisussa: Anneli Hopponen (toim.). Maataloustieteen Päivät 12.-13.1.2010. 